\title{
Obtaining urea-formaldehyde foam materials with improved mechanical properties
}

\author{
T.E.Rymar, V.V.Unkovskaja \\ V. Dahl East Ukrainian National University, 59A Tsentralny Prospect, \\ 93400 Severodonetsk, Ukraine
}

\section{Received November 8, 2016}

\begin{abstract}
The article presents the results of study of gas-filled material macrostructure based on urea-formaldehyde resin and liquid glass granular filler, obtained by chemical foaming using a variety of the gas-generating agents. There have been researched the influence of amount and type of the gas-generating agent, ratio of the granular filler to urea-formaldehyde binder on the transverse diameter of pores, coefficient of their shape and degree of inhomogeneity of the foam material structure. There have been determined the optimum gas-generating agent and its amount; the optimum ratio of the granular filler to urea-formal-
\end{abstract} dehyde binder to obtain foam material with homogeneous fine porous structure.

Keywords: urea-formaldehyde resin, gas-generating agent, foam materials, foaming, structure.

Исследована макроструктура газонаполненного материала на основе карбамидоформальдегидной смолы и жидкостекольного гранулированного наполнителя, полученного путем химического вспенивания, с помощью различных газообразующих агентов. Исследовано влияние количества и вида газообразующего агента, соотношения гранулированного наполнителя к карбамидоформальдегидному связующему на поперечный диаметр ячеек, коэффициент их формы и степень неоднородности структуры пеноматериала. Определены оптимальный газообразующий агент и его количество, оптимальное отношение гранулированного наполнителя к карбамидоформальдегидному связующему для получения пеноматериала с однородной мелкопористой структурой.

Вивчення структури карбамідоформальдегідного піноматеріалу з використанням гранульованого рідкоскляного наповнювача. T.E.PUлар, T.E. Унковська.

Досліджено макроструктуру газонаповненого матеріалу на основі карбамідоформальдегідної смоли і рідкоскляного гранульованого наповнювача, отриманого шляхом хімічного спінювання, за допомогою різних газоутворюючих агентів. Досліджено вплив кількості та виду газоутворюючого агента, співвідношення гранульованого наповнювача до карбамідоформальдегідного зв'язуючого на поперечний діаметр осередків, коефіцієнт їх форми і ступінь неоднорідності структури піноматеріалу. Визначено: оптимальний газоутворюючий агент і його кількість, оптимальне співвідношення гранульованого наповнювача до карбамідоформальдегідного зв'язуючого для отримання піноматеріалу з однорідною дрібнопористою структурою.

\section{Introduction}

Thermal insulation materials include light and usually porous materials that have a low thermal conductivity coefficient. Quality parameters of the thermal insulation materials are determined by features of their pore structure. Specificity of pores (predominance of closed porosity, presence of intergranular openings) determines not only good thermal properties of the insulation materials, but also stability of their quality indicators in general $[1,2]$. 
Foam plastic can be prepared from most synthetic and many natural polymers. However, foam plastics for industrial purposes are produced mainly on the basis of polystyrene, polyurethanes, polyethylene, epoxy and urea resins. The industry produces rigid and elastic foam plastics with a cell size of $0.02-2 \mathrm{~mm}$. They possess a low apparent density $\left(20-500 \mathrm{~kg} / \mathrm{m}^{3}\right)$ and excellent heat and sound insulation properties. Mechanical and electrical properties of the plastic foams depend on the structure peculiarities of the finished product. Plastic foams based on urea oligomers are one of the first gas-filled plastics, which are widely used as the thermal insulation material. Previously, this foam plastic was called "microporous rubber". The thermal conductivity coefficient of these materials is close to the thermal conductivity coefficient of air $(0.023 \mathrm{~W} / \mathrm{m} \cdot \mathrm{K})$. Microporous rubber can be operated at $95-100^{\circ} \mathrm{C}$ and for a short time (during $4-8 \mathrm{~h}$ ) at $140-180^{\circ} \mathrm{C}$. The microporous rubber is a non-flammable material. Urea plastic foams are resistant to influence of most corrosive media; they possess good adhesion to asbestos cement, wood, etc. The microporous rubber is used as protective material in nuclear engineering, building, refrigeration engineering [3]. However, it has low compressive strength. The material is used in the form of light filler of frame structures or voids [1].

There is another thermal insulation material, which is included in the urea foam plastics. This is glass-foam urea. It is prepared on the basis of urea-formaldehyde resins (UFR) [4]. In contrast to casting foam plastics, while being produced, the foam is first made of resin, and then the foam fills intergranular openings of expanded porous glass granules. The advantage of this material over traditional urea foam plastics is significant reduction in shrinkage deformation. The bulk weight of the glass-foam urea is $60 \mathrm{~kg} / \mathrm{m}^{3}$, compression strength is $0.04-0.08 \mathrm{MPa}$, thermal conductivity is $0.04 \mathrm{~W} /\left(\mathrm{m} \cdot{ }^{\circ} \mathrm{C}\right)$ [5]. One of the significant drawbacks of the glass-foam urea is small mechanical strength [6].

The purpose of this work is to increase strength and deformation properties of urea-formaldehyde foam plastic by means of regulation of its porous structure. This can be achieved by adding granular liquid glass filler into the foam plastic composition, as the result expandable binder smoothly fills the space between the filler granules. It allows forming a uniform fine-meshed struc- ture, which positively affects physical, mechanical, and thermal insulation properties of the urea foam plastic.

\section{Experimental}

The proposed urea-formaldehyde foam plastic is obtained from a two-component system of binder and expanded liquid glass granules [7]. The first component of the binder is a mixture of UFR, foam stabilizer, gas-generating agent (calcium carbonate and sodium hydrogen carbonate) and mineral filler. The choice of the gas-generating agents was made on the basis of literature data [3] and explained by such a property of the selected gas-generating agents as compatibility with UFR, as well as availability and cheapness. The second component is acid curing catalyst, which is a catalyst system based on orthophosphoric acid and ethylene glycol. The use of orthophosphoric acid in this work is explained by its quite rapid catalytic action and lower corrosive activity than other strong acids $(\mathrm{HCl}$, $\mathrm{H}_{2} \mathrm{SO}_{4}$ ). In addition, orthophosphoric acid helps to obtain stable foam and gives foam plastic additional flame retardant properties [8]. Ethylene glycol is added to the foam plastics to slow the foaming process, to eliminate brittleness, and to increase concentration of the acid catalyst in the composition.

The foam materials are obtained by mixing granules and binder components, casting the composition into specific moulds, in which they are foamed and hardened, and then dried at ambient temperature (20$25^{\circ} \mathrm{C}$ ). The obtaining of thermal insulation materials takes place in three stages: 1 . Mixing of UFR with additives (surfactant, filler, gas-generating agent). 2. Adding expanded granules into the obtained mixture. 3 . Adding the catalyst system into the composition, as a result the composition is foamed and hardened. After the composition is hardened, the block is removed from the mould and left to finally dry to constant weight at the room temperature for 10 days. During this time, the thermal insulation material gains maximum strength.

The strength limits at compression and bending in accordance with GOST 17177-94, the pores transverse diameter, the pores shape coefficient and the degree of inhomogeneity of the foam structure are determined according to the procedure "Determination of the Average Pore Size in Foam Plastic" [9]. The transverse diameter of pores is calculated by Formula 1: 
Table. Macrostructure indicators of foamed block thermal insulation material depending on amount of gas-generating agent

\begin{tabular}{|c|c|c|c|c|c|}
\hline \multirow{2}{*}{\multicolumn{2}{|c|}{$\begin{array}{c}\text { Gas-generating agent } \\
\text { (pts·wt.) }\end{array}$}} & \multicolumn{4}{|c|}{ Macrostructure indicator } \\
\hline & & \multirow{2}{*}{$\begin{array}{c}D \text { at shear, transverse } \\
\text { to foaming, sm }\end{array}$} & \multirow{2}{*}{$\begin{array}{c}D \text { at shear, parallel } \\
\text { to foaming, sm } \\
0\end{array}$} & \multirow{2}{*}{$\alpha$} & \multirow{2}{*}{$\begin{array}{r}\mathrm{K}, \% \\
0 \\
\end{array}$} \\
\hline Calcium Carbonate & 0 & & & & \\
\hline & 1 & 0.054 & 0.044 & 0.97 & 15.7 \\
\hline & 2 & 0.055 & 0.046 & 0.9 & 21.7 \\
\hline & 3 & 0.058 & 0.05 & 0.89 & 26.4 \\
\hline & 4 & 0.064 & 0.05 & 0.74 & 36.6 \\
\hline & 5 & $0,0.3$ & 0.064 & 0.69 & 38.1 \\
\hline \multirow{6}{*}{$\begin{array}{l}\text { Sodium Hydrogen } \\
\text { Carbonate }\end{array}$} & 0 & 0 & 0 & 0 & 0 \\
\hline & 1 & 0.042 & 0.041 & 0.7 & 14.1 \\
\hline & 2 & 0.053 & 0.051 & 0.69 & 16.9 \\
\hline & 3 & 0.054 & 0.052 & 0.69 & 22.1 \\
\hline & 4 & 0.061 & 0.053 & 0.64 & 28.9 \\
\hline & 5 & 0.069 & 0.058 & 0.6 & 37.5 \\
\hline
\end{tabular}

$$
D=2 \cdot \sqrt{\frac{S}{n \cdot \pi} \cdot\left(1-\frac{\rho}{d}\right)}
$$

where $D$ is the transverse diameter of pores, $\mathrm{cm} ; S$ is the shear area on which pores are counted, $\mathrm{cm}^{2} ; n$ is the number of pores in area $S ; \rho$ is the density of foam plastic, $\mathrm{g} / \mathrm{cm}^{3} ; d$ is the density of polymer, $\mathrm{g} / \mathrm{cm}^{3}$.

The pores shape coefficient is determined after additional counting of the number of pores in the certain shear area, parallel to the foaming direction. The calculation is based on Formula 2:

$$
\alpha=\frac{S_{1} \cdot n}{n_{1} \cdot S},
$$

where $\alpha$ is the pores shape coefficient; $S_{1}$ is the shear area parallel to foaming, on which pores are counted, $\mathrm{cm}^{2} ; n_{1}$ is the number of pores on area $S_{1} ; S$ and $n$ are respectively the area and the number of pores on the shear perpendicular to foaming.

Evaluation of the degree of inhomogeneity of the foam plastic structure is carried out by relative change in the pore diameter in different places of the block and it is calculated by Formula 3:

$$
K=\frac{\Delta c p}{D i} \cdot 100
$$

where $\Delta D i=D i-D c p, \Delta D c p$ is the average value of $\Delta D i$; $D i$ is the individual value of $D$ in different places of the block.

\section{Results and discussion}

The studied indicators of the foam material macrostructure with use of calcium carbonate and sodium hydrogen carbonate are presented in Table.

As it can be seen from Table, when the amount of the gas-generating agent increases, the number of pores decreases and, consequently, their transverse diameter increases. This is explained by the fact that a large number of pores are broken and their unification takes place due to the high rate of gas release. Apparently, it happens due to increase in mobility of the molecular chains of the initial urea resin, which leads to decrease in the surface tension of the foamed composition due to formation of poly-layers on the surface of the granular filler and, consequently, increase in the pore size. As a result, coarsely dispersed foam is formed with a small number of closed and a large number of open pores. The smallest pore diameter is observed when sodium hydrogen carbonate is used as the gas-generating agent in amount of 1 pts.wt., i.e. $0.041 \mathrm{~cm}$, and the degree of the structure inhomogeneity is $14.1 \%$. The largest pore diameter is observed when calcium carbonate is used as the gas-generating agent in amount of 5 pts.wt., i.e. $0.083 \mathrm{~cm}$. Such materials have inhomogeneous structure (the degree of inhomogeneity of the structure is $38.1 \%$ ), and as a consequence, the low strength. In the work we also determine the coefficient of the cell shape, which shows the direction of their elongation. As it can be seen, all the values of the coefficient are less than one; this 

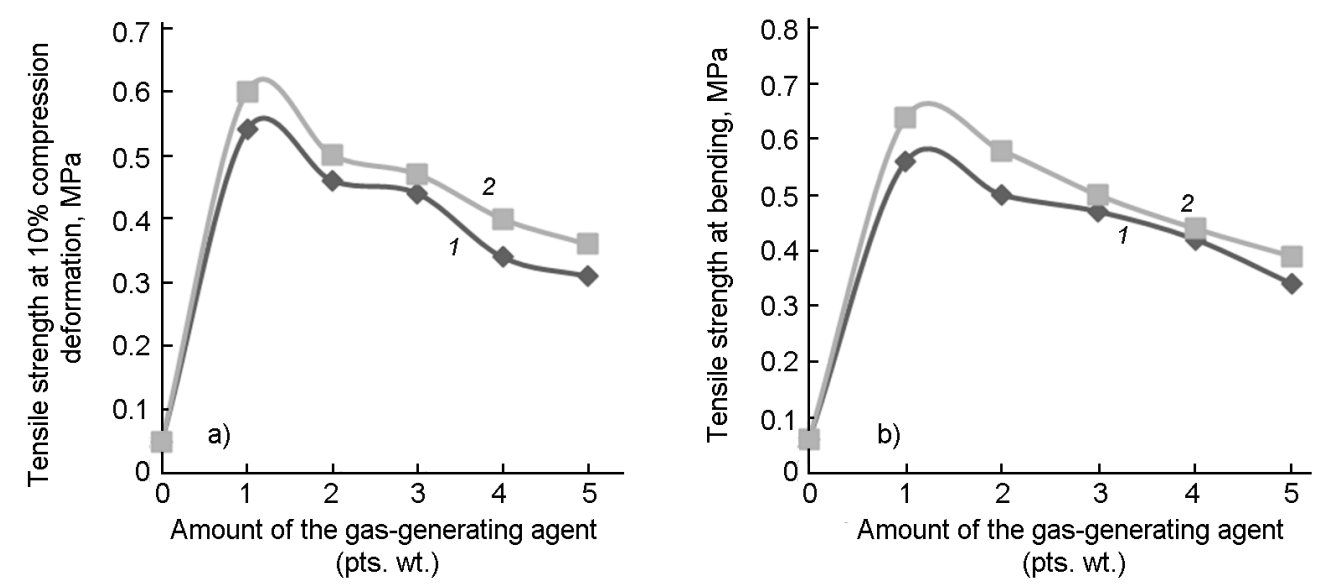

Fig. 1. Influence of amount of gas-generating agent on tensile strength: (a) at $10 \%$ compression deformation and (b) at foam material bending ( 1 - calcium carbonate, 2 - sodium hydrogen carbonate).

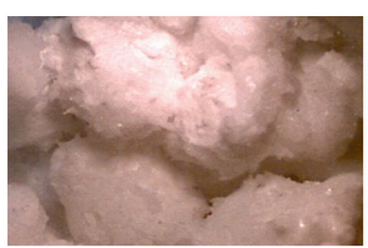

a)

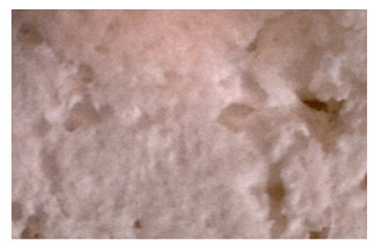

c)

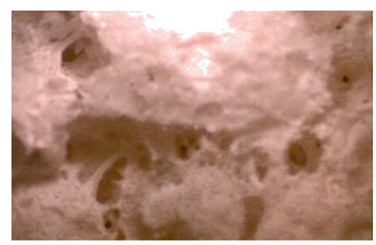

e)

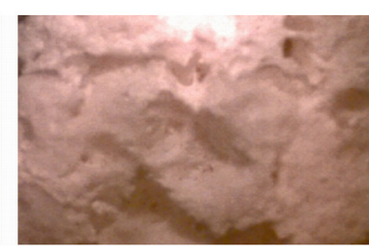

b)

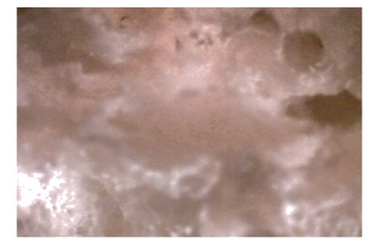

d)

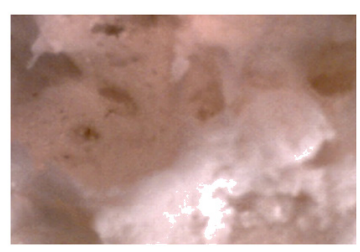

f)

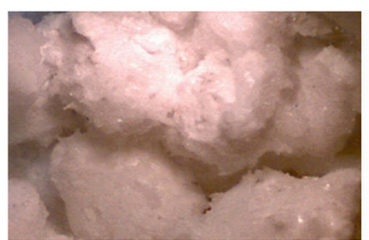

a)

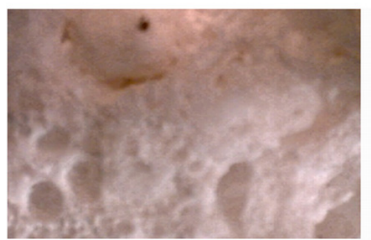

c)

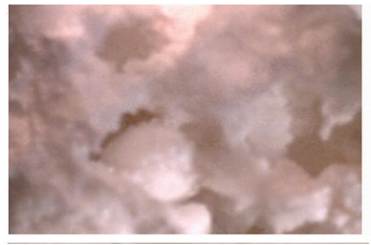

e)

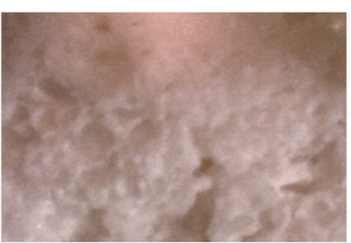

b)

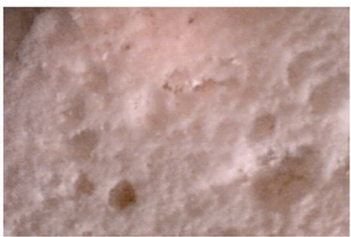

d)

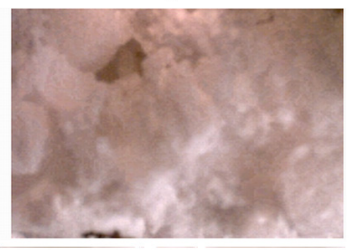

f)

Fig. 2. Macrostructure of the foam material containing various amounts of calcium carbonate (60-fold increase): a) 0 pts.wt. b) 1 pts.wt.; c) 2 pts.wt.; d) 3 pts.wt.; e) 4 pts $\cdot w t . ;$ f) 5 pts $\cdot w t$.

indicates that pores are elongated in the direction parallel to the foaming.

Influence of the amount of the gas-generating agent on the tensile strength at $10 \%$ compression deformation and bending of the foam material is shown in Fig. 1.

According to Fig. 1 the greatest tensile strength at $10 \%$ compression deformation and bending, namely $0.60 \mathrm{MPa}$ and $0.64 \mathrm{MPa}$ respectively using sodium hydrogen carbonate, and $0.54 \mathrm{MPa}$ and $0.56 \mathrm{MPa}$ respectively using calcium carbonate, is observed in the material with the highest den-

Fig. 3. Macrostructure of the foam material containing various amounts of sodium hydrogen carbonate (60-fold increase): a) 0 pts.wt. b) 1 pts.wt.; c) 2 pts.wt.; d) 3 pts.wt.; e) 4 pts.wt.; f) 5 pts.wt.

sity, for the production of which the gas-generating agent was used in amount of $1 \mathrm{pts} \cdot \mathrm{wt}$. With further increase in the amount of the gas-generating agent, the density decreases, pore size increases and the strength of blocks decreases (for $5 \mathrm{pts} \cdot \mathrm{wt}$. of calcium carbonate bending strength of the material is $0.34 \mathrm{MPa}$, and in the case of sodium hydrogen carbonate is $0.39 \mathrm{MPa}$ ).

Figures 2 and 3 show the macrostructure of the thermal insulation material containing different amount of the gas-generating 


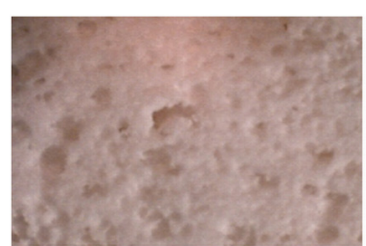

a)

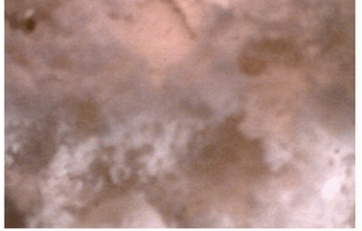

c)

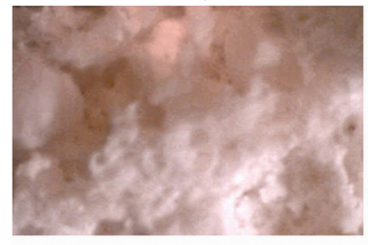

e)

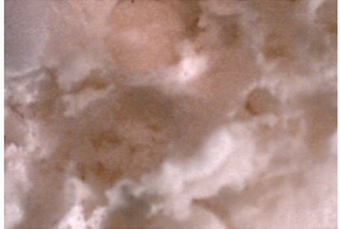

b)

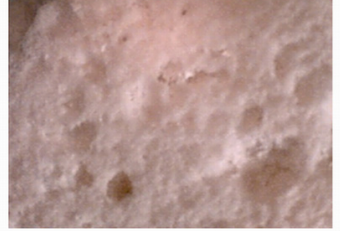

d)

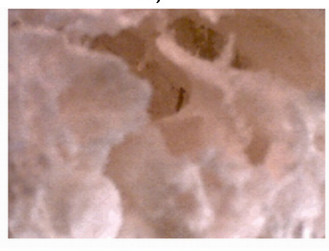

Fig. 4. Macrostructure of the foam material with different ratios of the amount of the granular filler to the binder, containing $3 \mathrm{pts} \cdot \mathrm{wt}$. of calcium carbonate $(60$-fold increase): a) without granules; b) $1: 1.5$; c) $1: 2$; d) $1: 2.5$; e) $1: 3$; f) $1: 3.5$.

agent: calcium carbonate (Fig. 2) and sodium hydrogen carbonate (Fig. 3).

In Fig. 2 and 3 it can be seen that without the gas-generating agent the block is not foamed, the binder concentrates only on the granules, and pores are absent. Quantity of $1 \mathrm{pts} \cdot \mathrm{wt}$. of the gas-generating agent is not enough, since a small number of pores and, as a consequence, high density are observed in the material. Too large pores are formed in the samples when the gas-generating agent quantity is 4 and 5 pts.wt., which negatively affects the thermal insulation properties and the material is characterized by low strength values. It can be concluded that the amount of calcium carbonate and sodium hydrogen carbonate of $3 \mathrm{pts} \cdot \mathrm{wt}$. gives the foamed block material the even fine porous structure with a large number of fine pores in combination with low density, which helps to cope with shrinkage phenomena during drying of the material, and also gives additional strength to the material.

Next, in Fig. 4 and 5 the macrostructure of the foam material is presented depending on the ratio of amount of the granular material to the binder containing $3 \mathrm{pts} \cdot \mathrm{wt}$. of calcium carbonate and $3 \mathrm{pts} \cdot \mathrm{wt}$. of sodium hydrogen carbonate respectively.

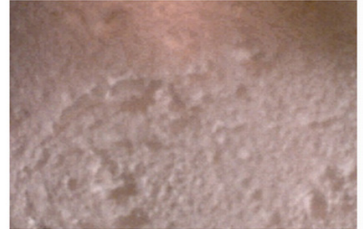

a)

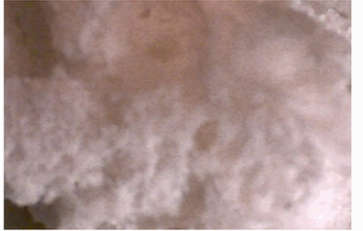

c)

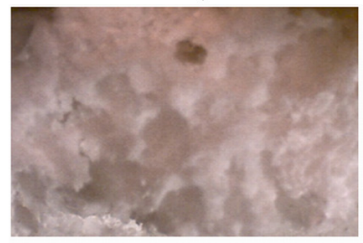

e)

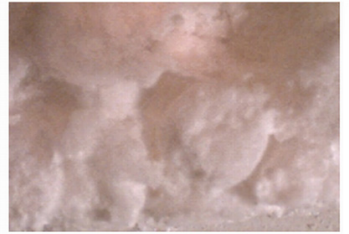

b)

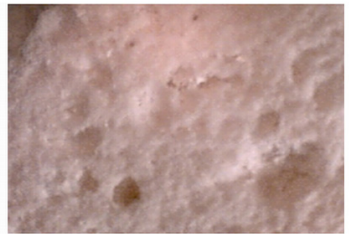

d)

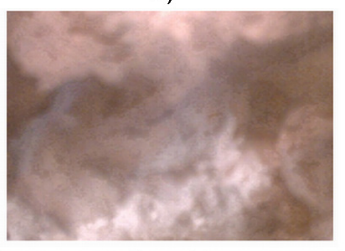

f)
Fig. 5. Macrostructure of the foam material with different ratios of the amount of the granular filler to the binder, containing 3 pts.wt. of calcium hydrogen carbonate (60fold increase): a) without granules; b) $1: 1.5$; c) $1: 2$; d) $1: 2.5$; e) $1: 3$; f) $1: 3.5$.

In Fig. 4 and 5 it can be seen that the optimal ratio of the granular filler to the binder for both calcium carbonate and sodium hydrogen carbonate is $1: 2.5$, because even fine-meshed structure with larger units of the cell structure is formed in the block material, which positively affects the physical and mechanical properties of the urea foam. At the quantity of $1: 1.5$ the granules are not completely covered with the binder and protrude, that is why the surface of the block is knobby and pores are practically absent. When the ratio of the granular filler to the binder is $1: 3-1: 3.5$, too large pores are formed in the samples; the effect of variations in thickness of the cell structure elements is manifested due to uneven distribution of the granular filler in the cells of the cell structure. Such foam plastics are characterized by large undeformable units and thin elongated strands, so the material would have the low strength properties.

\section{Conclusions}

The optimal gas-generating agent is sodium hydrogen carbonate in the amount of $3 \mathrm{pts} \cdot \mathrm{wt}$. at the ratio of the granular filler to the binder of $1: 2.5$. Such samples have stable homogeneous structure in combina- 
tion with the low density, the diameter of their pores and the degree of inhomogeneity of the structure are $0.054 \mathrm{~cm}$ and $22.1 \%$, and the tensile strength at $10 \%$ compression deformation and at bending are $0.47 \mathrm{MPa}$ and $0.50 \mathrm{MPa}$, respectively.

Thus, adding the granular filler contributes to formation of the fine-meshed structure, and makes it possible to reduce internal stresses in the foam material and to obtain the foam material with increased strength properties (the tensile strength at $10 \%$ compression deformation of known urea foam plastics is: for urea formaldehyde foam insulation $0.1-0.25 \mathrm{MPa}$ [10], omiflex $-0.19 \mathrm{MPa}$ [11], glass-foam urea 0.04-0.08 $\mathrm{MPa}$ [5], and the proposed thermal insulation material $-0.47 \mathrm{MPa}$ ).

\section{References}

1. Thermal Insulation Materials (Types and Properties) [Electronic Resource], Access Mode: http://rosbp.com/products/other/?action $=$ pubs\&id $=32$

2. A.I.Kudyakov, T.N.Radina, M.Yu.Ivanov, Build. Mat., No.11, 12 (2004).

3. V.Yu.Chukhlanov, Training Manual., 3 (2008).
4. Liquid Glass Products [Electronic Resource], Access Mode: http://stroivagon.ru/stroitelstvo/izdeliya-iz-zhidkogo-stekla

5. M.F.Sukharev, Production of Thermal Insulation Materials, Vyssh. Shkola, Moscow (1981).

6. I.S.Tabueva, A.Yu.Kanaev, I.A.Khristoforova, Text of Scientific Work of the VI Intern. Student Electron. Sci. Conf.

"Student Scientific Forum", February 15 March 31, 2014.

7. E.Yu.Kryuchkova, T.E.Rymar, Bull. Nat. Tech. Univ. KhPI, 30, 59 (2015).

8. Obtaining Urea Foam Plastics with Activated Fillers [Electronic Resource], Access Mode: http://msd.com.ua/teploizolyacionnye-penopl asty-na-osnove-karbamidnyx-smol-s- aktivirovannymi-napolnitelyami/poluchenie-karbam idnyx-penoplastov-s-aktivirovannymi-napolni telyami-4/

9. Rigid and Polyisocyanurate Foam Plastics. Technical Specifications: STB $1338-2002$, [Enacted on August 22, 2002], Moscow, State Standard of the Republic of Belarus, No.36, (2002).

10. E.G.Ovcharenko, Train. Manual., 122 (2003).

11. Thermal Insulation Omiflex M40 Boards in Krasnoyarsk [Electronic Resource], Access Mode: http://krasnoyarsk.mirstroek.ru/cata$\log /$ moreinfo/?id=16474 